\title{
Diffuse Malignant Mesothelioma
}

National Cancer Institute

\section{Source}

National Cancer Institute. Diffuse Malignant Mesothelioma. NCI Thesaurus. Code C8420.

A malignant neoplasm that arises from the mesothelial cells. Histologic variants include biphasic, epithelioid, sarcomatoid, and desmoplastic mesothelioma. 